\title{
An in vitro Study to Assess the Potential of a Unique Micro porous Algal Derived Cap Bone Void Filler in Comparison with Clinically-Used Bone Void Fillers
}

\author{
PJ Walsh ${ }^{1 *}$, SA Clarke1, J Nelson', CA. Maggs¹, GM Walker ${ }^{2}$ and FJ Buchanan ${ }^{3}$ \\ ${ }^{1}$ School of Biological Sciences, Queens University of Belfast, Northern Ireland, UK \\ ${ }^{2}$ Schools of Chemistry and Chemical Engineering, Queens University of Belfast, Northern Ireland, UK \\ ${ }^{3}$ School of Mechanical and Aerospace Engineering, Queens University of Belfast, Northern Ireland, UK
}

\begin{abstract}
Macroporosity $(>100 \mu \mathrm{m})$ in bone void fillers is a known prerequisite for tissue regeneration, but recent literature has highlighted the added benefit of microporosity $(0.5-10 \mu \mathrm{m})$. The aim of this study was to compare the in vitro performances of a novel interconnective microporous hydroxyapatite (HA) derived from red algae to four clinically available macroporous calcium phosphate $(\mathrm{CaP})$ bone void fillers. The use of algae as a starting material for this novel void filler overcomes the issue of sustainability, which overshadows continued use of scleractinian coral in the production of some commercially available materials, namely Pro-Osteon ${ }^{\mathrm{TM}}$ and Bio-Coral ${ }^{\circledR}$. This study investigated the physicochemical properties of each bone voidfiller material using x-ray diffraction, fourier transform infrared spectroscopy, inductive coupled plasma, and nitrogen gas absorption and mercury porosimetry. Biochemical analysis, XTT, picogreen and alkaline phosphatase assays were used to evaluate the biological performances of the five materials. Results showed that algal HA is non-toxic to human foetal osteoblast (hFOB) cells and supports cell proliferation and differentiation. The preliminary in vitro testing of microporous algal-HA suggests that it is comparable to the four clinically approved macroporous bone void fillers tested. The results demonstrate that microporous algal HA has good potential for use in vivo and in new tissue engineered strategies for hard tissue repair.
\end{abstract}

Keywords: Bone Void Filler; Calcium Phosphate Bioceramic; Algae; hFOBS

\section{Introduction}

The purpose of bone void fillers, besides filling a bone defect, is to encourage new bone growth by providing structural support for blood clotting and bone remodelling [1]. Ideally, the bone void filler should be resorbed and replaced through sequential remodelling cycles that are synchronised with the natural remodelling process. This will ensure that mechanical stability and metabolic function are maintained at the defect site and minimise the risk of failure from infection $[2,3]$. Over recent years, an increasing number of synthetic bone substitutes have become clinically available as alternatives to traditional graft materials $[4,5]$. Despite this, clinicians preferentially choose autologous bone graft, as synthetic alternatives still fail to match their in vivo performance [6,7].

The majority of synthetic bone void fillers tend to be HA, or related $\mathrm{CaP}$ ceramics, due to their similarity to bone mineral, which is approximately $60 \%$ HA by weight [8]. Research into naturally derived and synthetic $\mathrm{CaP}$ bone void fillers has focused mainly on the design and regulation of material properties to augment tissue regeneration. In more recent years, the focus has shifted towards the "intelligent biomaterial" which delivers active pharmacological compounds and/ or biological entities, such as morphogenic proteins, genes and growth factors, to enhance and accelerate regeneration [9].

There is, however, still a lack of understanding of critical physicochemical factors, which influence specific biological responses. For example, the role of microscale $(0.5-10 \mu \mathrm{m})$ and macroscale $(>100 \mu \mathrm{m})$ porosity to induce ectopic bone formation [10,11]. It has been well established that macroporosity with pores and interconnections $>100 \mu \mathrm{m}$ improves osteogenic outcomes [12]. The role of microporosity and/or multi-scale porosity in osteogenesis is still not clear. Several studies have reported the negative effects of microporosity with regard to fibrous ingrowth, reduced cell viability and restricted cell ingrowth $[13,14]$. Other more recent in vivo studies, however have clearly found that microporosity enhances bone regeneration by modulating osteogenic differentiation $[15,16]$, enhancing mechanical properties with more efficient load transfer [17], and improving bioresorption [18].

Mineralised biological tissues in nature, such as bone, teeth, mollusk shells, and coral, have shown that hierarchical structures with interconnected meso $(2-50 \mathrm{~nm})$, micro $(0.5-10 \mu \mathrm{m})$ and macro $(>100 \mu \mathrm{m})$ pores are crucial to biological function 19]. The ability to replicate these hierarchical structures in purely synthetic biomaterials has proven to be one of the most demanding manufacturing challenges in the field. Several techniques exist to produce porous bioceramics; but techniques to produce interconnected porous structures are much more limited. Templating is the only manufacturing technique that has shown any real potential, however it relies heavily on the existence of suitable templates [20,21] - those currently investigated include polymer foams, hydrogels, emulsions, composites on block copolymer and surfactants, bovine bone, marine sponges and corals [20,22].

Pro-Osteon ${ }^{\mathrm{TM}}$ and Biocoral ${ }^{\circledR}$ are two coral-derived commercially available products currently on the market. These materials have been

*Corresponding author: PJ Walsh, School of Biological Sciences, Queens University of Belfast, Northern Ireland, UK, E-mail: pamela.walsh@qub.ac.uk

Received June 03, 2011; Accepted July 20, 2011; Published July 22, 2011

Citation: Walsh PJ, Clarke SA, Nelson J, Maggs CA, Walker GM, et al. (2011) An in vitro Study to Assess the Potential of a Unique Micro porous Algal Derived Cap Bone Void Filler in Comparison with Clinically-Used Bone Void Fillers. J Tissue Sci Eng S1:002. doi:10.4172/2157-7552.S1-002

Copyright: ( 2011 Walsh PJ, et al. This is an open-access article distributed under the terms of the Creative Commons Attribution License, which permits unrestricted use, distribution, and reproduction in any medium, provided the original author and source are credited. 
Citation: Walsh PJ, Clarke SA, Nelson J, Maggs CA, Walker GM, et al. (2011) An in vitro Study to Assess the Potential of a Unique Micro porous Algal Derived Cap Bone Void Filler in Comparison with Clinically-Used Bone Void Fillers. J Tissue Sci Eng S1:002. doi:10.4172/2157-7552. S1-002

used clinically for more than 10 years and have performed similarly to other synthetic bone void fillers, exhibiting limited osteoinductivity in vivo [23,24]. The main benefit of coral-derived bone void fillers over synthetic alternatives is their bioresorption capacity $[25,26]$. Recently, other sustainable calcified marine structures and organisms, such as mussels [27, cuttlefish bone [28] and algae [26,29,30] have been investigated for bone void filler applications.

The aim of this study was to evaluate microporous $(0.5-10 \mu \mathrm{m})$ marine-based bioceramic granules (QUB $\mathrm{HA})$ in comparison to other more macroporous $(>100 \mu \mathrm{m})$ bovine (Bio Oss ${ }^{\circledR}$ ), synthetic (Bone Save) and marine-based (Pro-Osteon $^{\mathrm{TM}}$ ) commercial bioceramic granules. Our hypothesis is that the microporous granules will perform just as well as those with macroporosity in terms of the biological response. Each of these products has been manufactured differently [31-33], giving them a unique set of physicochemical attributes (Table 1). In this initial study, the physicochemical properties were studied using a wide range of analytical techniques [x-ray diffraction (XRD), fourier transform infrared spectroscopy (FTIR), inductive coupled plasmamass spectrometry (ICP-MS), nitrogen gas absorption $\left(S_{\mathrm{BET}}\right)$, mercury intrusionporosimetry (MIP)] to obtain a comprehensive overview of each material and preliminary in vitro testing of cell attachment, cell death, proliferation and differentiation.

\section{Materials and Methods}

\section{Materials}

Corallinaofficinalis was harvested from Fanad, Co. Donegal. It was processed into a biphasic calcium phosphate microporous bioceramic (QUB HA) by a low temperature-pressure synthesis technique reported previously $[34,35]$. Briefly, the algae samples were cleaned using: sodium hypochlorite $(\mathrm{NaOCl} ; 0.1 \mathrm{M})$, hydrogen peroxide $\left(\mathrm{H}_{2} \mathrm{O}_{2} ; 30\right.$ wt. \% in $\left.\mathrm{H}_{2} \mathrm{O}\right)$ and sodium hydroxide $(\mathrm{NaOH}, 0.5 \mathrm{M})$, to remove macroscopic dirt/impurities; then heat treated to isolate the inorganic compound. Heat treatment resulted in the partial conversion of algae from $\mathrm{Mg}$ rich-calcite to calcium oxide [36]. For synthesis, a stoichiometric ratio $(\mathrm{Ca} / \mathrm{P}=1.67)$ of heat treated algae was added to a 2 molar

Diammonium hydrogenphosphate (99.9\%; Sigma Aldrich) aqueous solution. The $\mathrm{pH}$ was adjusted in the range of 10-12 with ammonium hydroxide ( $28 \%$ in $\mathrm{H}_{2} \mathrm{O}$, Sigma Aldrich) and maintained throughout synthesis. The suspension was heated to $100^{\circ} \mathrm{C}$ in an open system reaction vessel under constant agitation for $12 \mathrm{hrs}$. It was then cooled and aged for $24 \mathrm{hrs}$ at room temperature. The residual phosphate was removed by soaking the granules in $10 \% \mathrm{v} / \mathrm{v} \mathrm{CH}_{3} \mathrm{COOH}$ for $1 \mathrm{hr}$ under agitation, which effectively removes the residual phosphate without dissolving synthesised phosphate[34,35]. The resultant granules were washed in $\mathrm{dH}_{2} \mathrm{O}$ until the wash solution reached a $\mathrm{pH} \sim 7$, filtered and dried overnight at $90^{\circ} \mathrm{C}$. Four different clinically available bone void filler materials were evaluated: 1) Bio Oss ${ }^{\circledR}$, GeistlichPharma; 2) Bone Save $^{\circledR}$, Stryker Osteonics; 3) Pro-Osteon ${ }^{\text {TM }}$ 200R and 4) Pro-Osteon ${ }^{\text {TM }}$ 500R, Biomet (Interpore) and compared to QUB HA.

\section{Material characterization}

Scanning Electron Microscopy (SEM) / Image Analysis (IA): SEM coupled with IA was used to determine pore size within the bone void filler materials. Granules were dispersed on the surface of an aluminium SEM stub coated with Araldite epoxy glue and then sputter coated with gold. Micrograph images were taken on a JEOL 6500 SEM microscope and imported into imaging software (Lucia). Manual point-to-point $(n=20)$ measurements were taken in each direction to determine the pore size, per image with 3 replications.
Nitrogen gas absorption $\left(S_{\mathrm{BET}}\right)$ : The specific surface areas, $\mathrm{m}^{2} \mathrm{~g}^{-1}\left(S_{\mathrm{BET}}\right)$, of the granules were determined using nitrogen adsorption isotherms measured on a FisonsSorptomatic 1900 analyser. The areas were calculated using Brunauer, Emmett and Teller (BET) multilayer method (QuantachromeTM NovaWin2 software). Before analysis, the granules were outgassed at $-73 \mathrm{~K}$ for $24 \mathrm{hrs}$.

Mercury intrusion porosimetry (MIP): A mercury porosimeter (QuantachromePoremaster) with a small penetrometer was used to determine the porosity of the bone void filler materials. Samples $(0.2-$ $0.4 \mathrm{gs})$ were analysed with a contact angle of $140^{\circ}$ and surface tension of $480.00 \mathrm{ergcm}^{-2}$.The theoretical porosity was calculated from the total intrusion volume.

\section{Inductively coupled plasma-mass spectrometry (ICP-MS)}

Elemental analysis was performed to determine $\mathrm{Ca}, \mathrm{P}$ and $\mathrm{Mg}$ concentrations to calculate the $\mathrm{Ca} / \mathrm{P}$ and $\mathrm{Ca}+\mathrm{Mg} / \mathrm{P}$ molar ratios using a Perkin Elmer Optical Emission Spectrometer, Optima 4300DV. Prior to analysis the machine was calibrated to $10 \mathrm{ppm}$ with a detection limit of $0.01 \mathrm{mg} \mathrm{L}^{-1}$. Powdered samples were digested in $2 \% \mathrm{v} / \mathrm{v}$ nitric acid (ACS reagent, ISO, $\geq 69 \%$ ) in $\mathrm{dH}_{2} \mathrm{O}$ overnight and then diluted within the detection limit of the machine for analysis.

Powder X-ray diffraction (XRD): The bulk chemical composition of the materials was determined using XRD. Powder diffraction scans were recorded at room temperature using an X-Pert Pro $\mathrm{X}$-ray diffractometer system with an X'Celerator X-ray detector (PANanlyticalX'Pert PRO MPD; Model No. 135 PW3040/60) and $\mathrm{CuK}$ radiation. For phase identification, a step size of 0.02 and count rate of $0.0005 \mathrm{~min}^{-1}$ were used to obtain the spectra for between 10 and $70^{\circ}\left(2^{\circ} \theta\right)$. Scans were imported into X-Pert high score for analysis with reference data, then characterised using Rietveld refinement analysis.

Fourier Transform Infra-Red spectroscopy (FTIR) : FTIR was used to identify functional groups on the surface of the bone void filler materials. IR spectra were recorded on a Perkin-Elmer 1600 M-80 spectrometer. Spectra of powdered samples were collected in transmission mode from 124 scans, over a frequency range of 400 to $4400 \mathrm{~cm}^{-1}$, at a resolution of $4 \mathrm{~cm}^{-1}$.

\section{Biological characterization}

Cell culture: Cell culture experiments were performed using a transformed human fetal osteoblast (hFOB) cell line (LGC/ATCC, UK). Cells were cultured in DMEM/F-12 medium supplemented with $10 \%$ fetal bovine serum (FBS), $0.3 \mathrm{mgml}^{-1}$ geneticin and $200 \mathrm{mM}$ L-glutamine (all Invitrogen, UK).50 $\mu \mathrm{M}$ ascorbate-2-phosphate (Sigma,UK) was also added to the medium for the alkaline phosphatase (ALP) experiment only. All assays were incubated in $5 \% \mathrm{CO}_{2}$ in air at the permissive (proliferative) temperature of $33^{\circ} \mathrm{C}$ (unless otherwise stated). All materials were sterilized by autoclaving at $121^{\circ} \mathrm{C}$ for 30 minutes in their original granular form. For each experiment, 100 to $120 \mathrm{mg} /$ well $(\approx 80 \%)$ of a 96 -well plate was evenly covered in bone void filler granules and then pre-wetted in culture medium for $24 \mathrm{hrs}$. Before seeding, the medium was removed and granules were washed twice in phosphate-buffer saline (PBS). In each assay, the granules and tissue culture polystyrene (TCP) without granules (control) were seeded with hFOBs at a density of $1 \times 10^{5}$ cells $^{-2}$ and fed bi-weekly with the appropriate medium. There were six replicates per experimental condition $(n=6)$ and for each assay readings were performed in duplicate for each well.

Cytotoxicity: Cytotoxicity was measured after $72 \mathrm{hrs}$ incubation using a CytoTox96 non-radioactive assay (Promega) according to the 
Citation: Walsh PJ, Clarke SA, Nelson J, Maggs CA, Walker GM, et al. (2011) An in vitro Study to Assess the Potential of a Unique Micro porous Algal Derived Cap Bone Void Filler in Comparison with Clinically-Used Bone Void Fillers. J Tissue Sci Eng S1:002. doi:10.4172/2157-7552. S1-002

manufacturer's instructions. This assay measures lactate dehydrogenase in the culture supernatant. Absorbance was read at a wavelength of $450 \mathrm{~nm}$ with a reference wavelength of 620 on a GENios plate reader (TECAN, Theale, U.K.)

Cell viability: Cell viability was observed colorimetrically at 1,3 and 7 days using an XTT assay (In vitro Toxicology Assay Kit, TOX2, and Sigma). Viability wasdetermined by the ability of metabolically active cells to reduce tetrazolium salts (2, 3-bis [2-Methoxy-4-nitro-5sulfophenyl]-2H-tetrazolium-5-carboxyanilide inner salt) to an orange formazan dye. The reagent was prepared according to manufacturer's instructions and a volume equal to $20 \%$ of the culture medium was added to each well. After $4 \mathrm{hrs}$ incubation at $33^{\circ} \mathrm{C}, 50 \mu \mathrm{l}$ aliquots were transferred in duplicate to a fresh 96-well plate and absorbance read at a wavelength of $450 \mathrm{~nm}$ with a reference wavelength of $620 \mathrm{~nm}$. Average absorbance values from medium-only wells were subtracted from net absorbance values $(620-450 \mathrm{~nm})$ for each experimental group.

Cell proliferation: Cell proliferation was determined by measuring the DNA content of cell lysates using a PicoGreen ${ }^{\circledR} \mathrm{dsDNA}$ Quantification Kit (Invitrogen). At each time point (1, 3 and 7 days) the culture medium was replaced with $0.1 \% \mathrm{v} / \mathrm{v}$ Triton X-100 in PBS and frozen at $-80^{\circ} \mathrm{C}$. Cells were lysed by three freeze/thaw cycles and the assay performed as per manufacturer's instructions. Samples were analysed at wavelengths of 480nm (excitation) and 520nm (emission).

Cell differentiation: ALP enzymatic activity was used as a maker of cell differentiation. ALP activity was measured using the substrate p-nitrophenyl phosphate (Sigma-Aldrich, UK) in an end-point assay. After seeding hFOBs onto each material in complete medium supplemented with ascorbate-2-phosphate, cells were incubated at $33^{\circ} \mathrm{C}$ for $24 \mathrm{hrs}$, followed by incubation at the restrictive (differentiating) temperature of $39^{\circ} \mathrm{C}$ for a further 3 and 7 days. Cells were lysed as described in section 2.3.4 and 501 aliquots were added in duplicate to a 96-well plate with $200 \mu$ l of $p$-nitrophenyl phosphate and incubated for 30 mins. The reaction was stopped by the addition of $1 \mathrm{M} \mathrm{NaOH}$ solution and absorbance read at a wavelength of $405 \mathrm{~nm}$. The DNA content in each lysate was also measured using the PicoGreen ${ }^{\circledR}$ assay (described in section 2.3.4) and the ALP activity results are expressed per $\mu \mathrm{g}$ of DNA.

\section{Statistics}

Differences between materials and between time points were analysed using one-way ANOVA with post hoc Bonferroni's test using SPSS v13 software. Where individual comparisons were performed, an independent Student's t-test was used. $\mathrm{p}$ values $<0.05$ were considered significant. All data are expressed as mean \pm standard error.

\section{Results and Discussion}

\section{Physicochemical characterization}

This study compared the physicochemical properties and in vitro biological performance of five different bone void filler materials. The materials tested differ considerably with respect to their granular size, shape, pore size and chemical composition making direct comparison between specific material properties difficult when assessing their biological performance. When using granules as fillers in a bone defect, it is hypothesized that interstitial space between the granules will create additional macropores, enabling infiltration of boneforming cells around the granules. Therefore, the shape and size of the granules is important, as it will influence the size of the interstitial pores. For penetration and ingrowth of bone cells, pores and pore interconnections greater than $100 \mu \mathrm{m}$ are required $[1,12]$. Metabolizing cells also require an oxygen source in close proximity for survival; therefore the ability of the bone void filler to become vascularised will enhance the successfulness of the implant [37].

Morphological analysis: Four of the materials are classified as predominately macroporous with pores in the range of $100-900 \mu \mathrm{m}$. Slight variation in pore size was observed between pore size quoted by the manufacturer (Table 1) and those values calculated in-house (Table 2), owing to variation in characterisation techniques. Only QUB HA was classified as microporous, with pores in the range of 9 $-11 \mu \mathrm{m}$ (Table 2). It also had relatively small granules inthe range of 0.3 to $2 \mathrm{~mm}$, similar to Bio $\mathrm{Oss}^{\circledR}$ and Pro-Osteon ${ }^{\mathrm{TM}} 200 \mathrm{R}$, however, the granule shape and type of pores differs between commercial materials (Table 1). This is also evident in the SEM micrographs, Figure 1a-e. The morphological structure of Bio Oss ${ }^{\circledR}$ and ProOsteon $^{\mathrm{TM}} 200 \mathrm{R} / 500 \mathrm{R}$ is similar to cancellous bone, whereas Bone Save ${ }^{\mathrm{B}}$ has a lower porosity with mainly closed macropores. The granule

\begin{tabular}{|c|c|c|c|c|}
\hline Material & Bio Oss ${ }^{\circledR}$ & Bone Save $^{\circledR}$ & Pro Osteon ${ }^{\mathrm{TM}}$ 200R & Pro Osteon ${ }^{\mathrm{TM}} 500 \mathrm{R}$ \\
\hline Supplier & Geistlich Pharma & Stryker, Osteonics & Biomet, (Interpore) & Biomet, (Interpore) \\
\hline Type & Bovine & Synthetic & Coral & Coral \\
\hline Composition & Similar to human bone $(\mathrm{HA})$ & $80 \%$ TCP: $\quad 20 \% \mathrm{HA}$ & $\mathrm{HA}$-coated $\mathrm{CaCO}_{3}$ & $\mathrm{HA}$-coated $\mathrm{CaCO}_{3}$ \\
\hline Porosity & $70-75 \%$ & $50-55 \%$ & $50 \%$ & $65 \%$ \\
\hline Pore Size (m) & 100 & $300-500$ & $180-220$ & $270-650$ \\
\hline Pore Type & Interconnective & Closed Pores & Interconnective & Interconnective \\
\hline Shape & Irregular & Rounded & Rounded & Irregular \\
\hline Granule Size (mm) & $0.25-2$ & $2-8$ & $0.5-1$ & $2-10$ \\
\hline
\end{tabular}

Table 1: Physicochemical material properties of commercial CaP bone void fillers according to manufacturers' specifications.

\begin{tabular}{|c|c|c|c|c|c|}
\hline Material & Bio Oss ${ }^{\circledR}$ & Bone Save ${ }^{\circledR}$ & Pro Osteon ${ }^{\mathrm{TM}}$ 200R & Pro Osteon ${ }^{\mathrm{TM}}$ 500R & QUB HA \\
\hline QUB HA Granule Size $(\mathrm{mm})$ & $0.25-2$ & $2-8$ & $0.5-1$ & $2-10$ & $0.3-2(\varphi)^{c}$ \\
\hline Pore Size $(\mu \mathrm{m})^{\mathrm{b}}$ & $200-900$ & $300-500$ & $150-220$ & $200-650$ & $9-11$ \\
\hline Surface Area $\left(m^{2} g-1\right)^{c}$ & 94.60 & 2.29 & 9.13 & 9.38 & 129.8 \\
\hline Porosity $^{d}$ & $90.65 \pm 1.97$ & $85.01 \pm 5.61$ & $87.17 \pm 7.13$ & $88.67 \pm 11.84$ & $88.47 \pm 3.21$ \\
\hline
\end{tabular}

Table 2: Morphological characterization of CaPbone void fillers measured in-house.

a, b. Calculated by image analysis $(n=20)$

c. Calculated using BET ( $r 2=0.998 ; n=3)$

d. Calculated by MIP Theoretical Porosity $(n=3)$ 
Citation: Walsh PJ, Clarke SA, Nelson J, Maggs CA, Walker GM, et al. (2011) An in vitro Study to Assess the Potential of a Unique Micro porous Algal Derived Cap Bone Void Filler in Comparison with Clinically-Used Bone Void Fillers. J Tissue Sci Eng S1:002. doi:10.4172/2157-7552. S1-002

shape of QUB HA (Figure 1ei) is cylindrical with closely-spaced honeycomb-like pores and typical pore wall thickness of $1.5-2 \mu \mathrm{m}$, pore diameter of $>12 \mu \mathrm{m}$ (Figure 1eii) and pore length of $>100 \mathrm{~m}$ (parallel tobranch).These pores areinterconnected bymicroperforations of $1-4 \mu \mathrm{m}$, as characterised in a previous study 35]. According to the literature, this type of microporosity is unlikely to support osteogenesis [13].Microporesintherangeof0.2-1 $\mu$ marealsovisibleinBioOss ${ }^{\circledR}$ (Figure 1aii), Bone Save ${ }^{\circledR}$ (Figure 1bii) and Pro-Osteon ${ }^{\mathrm{TM}}$ 200R (Figure 1cii). A surface coating of fine needle-like crystal conglomerations are visible on Pro-Osteon ${ }^{\mathrm{TM}}$ 500R (Figure 1dii) which are typical of highly crystalline HA.

$S_{\text {BET }}$ of the bone void filler materials was measured using $\mathrm{N}_{2}$ gas absorption (Table 2), which takes into consideration only $S_{\text {BET }}$ of micro and mesopores. Bone Save ${ }^{\circledR}$, Pro-Osteon ${ }^{\mathrm{TM}} 200 \mathrm{R}$ and 500R were relatively low with a range of 2.29 to $9.38 \mathrm{~m}^{2} \mathrm{~g}^{-1}$, compared to 94.60 and $129.8 \mathrm{~m}^{2} \mathrm{~g}^{-1}$ for Bio Oss ${ }^{\circledR}$ and QUB HA respectively. The $S_{\mathrm{BET}}$ values for Pro-Osteon ${ }^{\mathrm{TM}}$ and Bone Save ${ }^{\circledR}$ were higher than those $\left(<1 \mathrm{~m}^{2} \mathrm{~g}^{-1}\right)$ reported in the literature for synthetic sintered HA bioceramics. Bio $\mathrm{Oss}^{\circledR}$ was found to be in the range of natural bone mineral, reported to be between 87 and $100 \mathrm{~m}^{2} \mathrm{~g}^{-1}$. QUB HA was also higher than those values $\left(17-82 \mathrm{~m}^{2} \mathrm{~g}^{-1}\right)$ reported in the literature for non-sintered HA [38]. The high $S_{\text {BET }}$ of QUB HA can be explained by a smaller particle size and high density of micropores. The bulk porosity of the void filler were characterised using MIP. The results (Table 2) showed all the materials have a porosity of $>85 \%$, which was significantly higher than those quoted by the manufacturers (Table 1). Interestingly, the MIP results for Pro-Osteon ${ }^{\mathrm{TM}} 200 \mathrm{R}$ and $500 \mathrm{R}$ have given similar porosity values of $87.17 \pm 7.13$ and $88.67 \pm 11.84$ respectively, despite having a different pore size range. In this instance, the micro/meso porosity may have played a role in balancing the overall porosities of the two materials.

Chemical analysis: The ICP-MS showed that the main elements in the bone void filler materials were calcium and phosphate with $\mathrm{CaP}$ molar ratios ranging from 1.48 to 4.44 (Table 3). Human bone mineral has a chemical formula of $\mathrm{Ca}_{83}\left(\mathrm{PO}_{4}\right)_{43}\left(\mathrm{OH}, \mathrm{CO}_{3}\right)_{03}$ with a CaP molar ratio in the range of 1.5 to 1.70 [39]. The $\mathrm{CaP}$ and $(\mathrm{Ca}+\mathrm{Mg}) / \mathrm{P}$ molar ratio of Bio Oss ${ }^{\circledR}$ and QUB HA was found to be similar to the stoichimetric value of human bone (Table 3). Bio Oss ${ }^{\circledR}$ was the only material tested that had the same composition to the mineral phase of human bone. The high molar ratios of 2.90 and 4.44 for Pro-Osteon ${ }^{\mathrm{TM}}$ $200 \mathrm{R}$ and $500 \mathrm{R}$ are a result of the manufacturing process as only the outer surfaces of the exoskeleton has been converted to HA (Table 1); the bulk of the sample remains $\mathrm{CaCO}_{3}$, which is evident from the high calcium content found in the ICP results.

Heavy metal contaminants were found to be well below the specified limit of BS ISO 13779-4 and therefore not reported [40]. The presence of magnesium $(\mathrm{Mg})$ ions in apatite structures is important as it plays a key role in bone metabolism; it has a marked inhibitory effect on HA nucleation and growth and stabilizes more acidic precursor phases [41]. Trace levels of $\mathrm{Mg}$ were found in all samples. Elevated levels of $\mathrm{Mg}$ were evident in Pro-Osteon ${ }^{\mathrm{TM}} 500 \mathrm{R}$, resulting in a significant increase between $\mathrm{CaP}$ and $(\mathrm{Ca}+\mathrm{Mg}) / \mathrm{P}$ molar ratios from 4.44 to 5.28 (Table 3). The CaP molar ratio of Bone Save ${ }^{\circledR}$ corresponds to the theoretical CaP ratio of 1.5 for $\mathrm{Ca}_{3}\left(\mathrm{PO}_{4}\right)_{2}$ materials, confirming the composition given by the manufacturer [32]. The next most abundant metallic ion found in bone is sodium. High trace amounts, $\sim 1.6 \mathrm{mg} / \mathrm{L}$, of $\mathrm{Na}$ ions were found

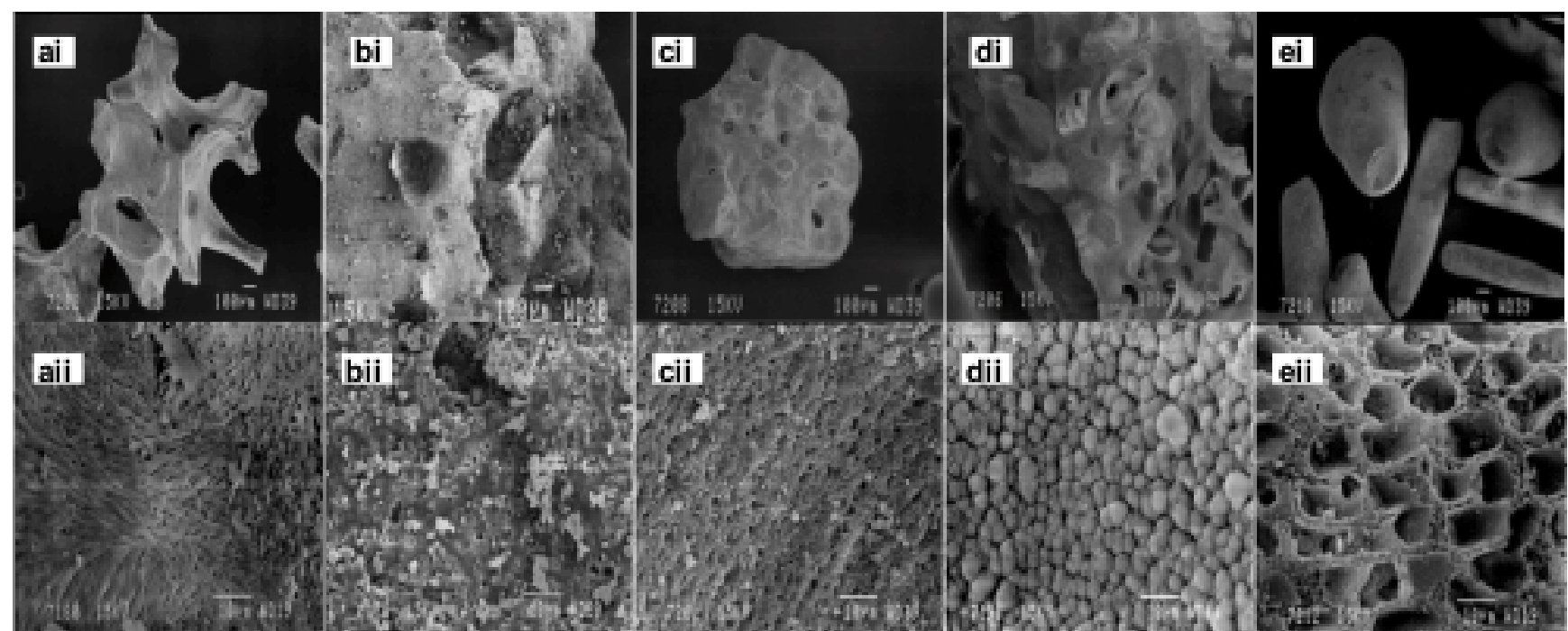

Figure 1: SEM micrographs of (a) Bio Oss (b) Bone Save (c) Pro-Osteon 200R ${ }^{\mathrm{TM}}$ (d) Pro-Osteon 500R ${ }^{\mathrm{TM}}$ and (e) QUB HA; ai-ei: Bars are 100 $\mu$ m (Magnification x50); aii-eii: Bars are $10 \mu \mathrm{m}$ (Magnification $\times 1500)$.

\begin{tabular}{|c|c|c|c|c|c|}
\hline Material & Bio Oss ${ }^{\circledR}$ & Bone Save $^{\circledR}$ & Pro Osteon ${ }^{\mathrm{TM}} 200$ & Pro Osteon ${ }^{\mathrm{TM}}$ 500R & QUB HA \\
\hline \multicolumn{6}{|l|}{ Major Elements } \\
\hline Ca/P Molar Ratio ${ }^{a}$ & 1.66 & 1.48 & 2.90 & 4.44 & 1.61 \\
\hline$(\mathrm{Ca}+\mathrm{Mg}) / \mathrm{P}$ Molar Ratio ${ }^{\mathrm{a}}$ & 1.70 & 1.49 & 2.93 & 5.28 & 1.70 \\
\hline \multicolumn{6}{|l|}{ Minor Elements (mg/L) } \\
\hline $\mathrm{Na}$ & $1.90 \pm 0.09$ & $0.91 \pm 0.01$ & $1.61 \pm 0.11$ & $1.98 \pm 0.36$ & $1.70 \pm 0.62$ \\
\hline $\mathrm{Si}$ & $0.22 \pm 0.05$ & $0.56 \pm 0.04$ & $0.22 \pm 0.01$ & $0.25 \pm 0.01$ & $0.40 \pm 0.05$ \\
\hline $\mathrm{Sr}$ & $0.07 \pm 0.02$ & $0.07 \pm 0.01$ & $2.46 \pm 0.87$ & $1.84 \pm 0.08$ & $0.15 \pm 0.02$ \\
\hline
\end{tabular}

Table 3: Ca/P Molar Ratio and minor components calculated from element's atomic mass andICP-MS analysis $(n=6)$. 
Citation: Walsh PJ, Clarke SA, Nelson J, Maggs CA, Walker GM, et al. (2011) An in vitro Study to Assess the Potential of a Unique Micro porous Algal Derived Cap Bone Void Filler in Comparison with Clinically-Used Bone Void Fillers. J Tissue Sci Eng S1:002. doi:10.4172/2157-7552. S1-002

Page 5 of 9

in all samples with the exception of the synthetic HA Bone Save ${ }^{\circledR}$. Other trace elements that were detected at elevated levels were silicon and strontium, both of which are known to enhance bone metabolism [41].

Four of the five bone filler samples investigated using FTIR show vibrational modes corresponding to phosphate, hydroxyl and carbonate groups found in HA (Figure 2). The exception was Bone Save ${ }^{\circledR}$, which matched those found in synthetic $\beta$ TCP 31]. In the four HA samples, intense bands at $1010-1050 \mathrm{~cm}^{-1}$ (strongest in Bio Oss ${ }^{\circledR}$, QUB HA) and $1426-1465 \mathrm{~cm}^{-1}$ were assigned to $v_{2} \mathrm{PO}_{4}^{3-}$, and are consistent with the subgroup of the $\mathrm{P}_{3} / \mathrm{m}$ space group of HA [42]. Other characteristic HA bands were observed at $850-875 \mathrm{~cm}^{-1}$ corresponding to $v_{2} \mathrm{CO}_{3}{ }^{2-}$ and lower intensity bands at $975-990 \mathrm{~cm}^{-1}$ shouldering $v_{2} \mathrm{PO}_{4}^{3-}$ assigned to $v_{1} \mathrm{PO}_{4}{ }^{3-}$ were also visible $[28,42]$. The $\mathrm{CO}_{3}{ }^{2-}$ bands at 1465 and $714 \mathrm{~cm}^{-1}$, and 1462 and $713 \mathrm{~cm}^{-1}$ in Pro-Osteon ${ }^{\mathrm{TM}} 200 \mathrm{R}$ and 500R respectively had a much higher intensity compared to the other samples and are likely to belong to unreacted aragonite in the coral [43]. Only one $\mathrm{CO}_{3}{ }^{2-}$ band was observed in QUB HA at $1471 \mathrm{~cm}^{-1}$. In addition a broadband was observed at $3000-3500 \mathrm{~cm}^{-1}$ which was assigned to $\mathrm{O}-\mathrm{H}$ stretching and is likely to be a result of water absorption in the sample [44].
XRD diffractograms for the five samples investigated are shown in Figure 3. All samples show the characteristic three peaks residing between 31 and $33^{\circ}(2 \theta)$, representing (211), (112), (300) planes and a more crystalline peak at $26^{\circ}(2 \theta)$ representing the (002) plane of HA [45]. The additional peaks were identified as belonging to unreacted calcite or aragonite, matched by the patterns (PDF 47-1473) and (PDF 41-1475) respectively. BioOss ${ }^{\circledR}$ and QUB HA were found to be poorly crystalline, similar to the crystallographic appearance of biological apatites. The sharp peaks found in the other samples indicate the presence of a highly crystalline material, which is a result of the high temperature processing conditions. The additional peaks in the samples were identified as corresponding to magnesium and $\beta$ TCP phases, matching patterns (PDF 09-0169) and (PDF 47-1473) respectively. Rietveld refinement was applied to the diffractograms to characterize the phase content. The least-square refinement program used for Rietvel showed that all the patterns were well resolved with the calculated profiles. The algal-derived QUB HA was matched to the profile (PDF 73-0294). The phase composition was $>95 \%$ HA, with minor phases of $\beta$ TCP and other impurities (Table 3). BioOss ${ }^{\circledR}$ and Bone Save ${ }^{\circledR}$ were found to have phase compositions of HA (100\%) and
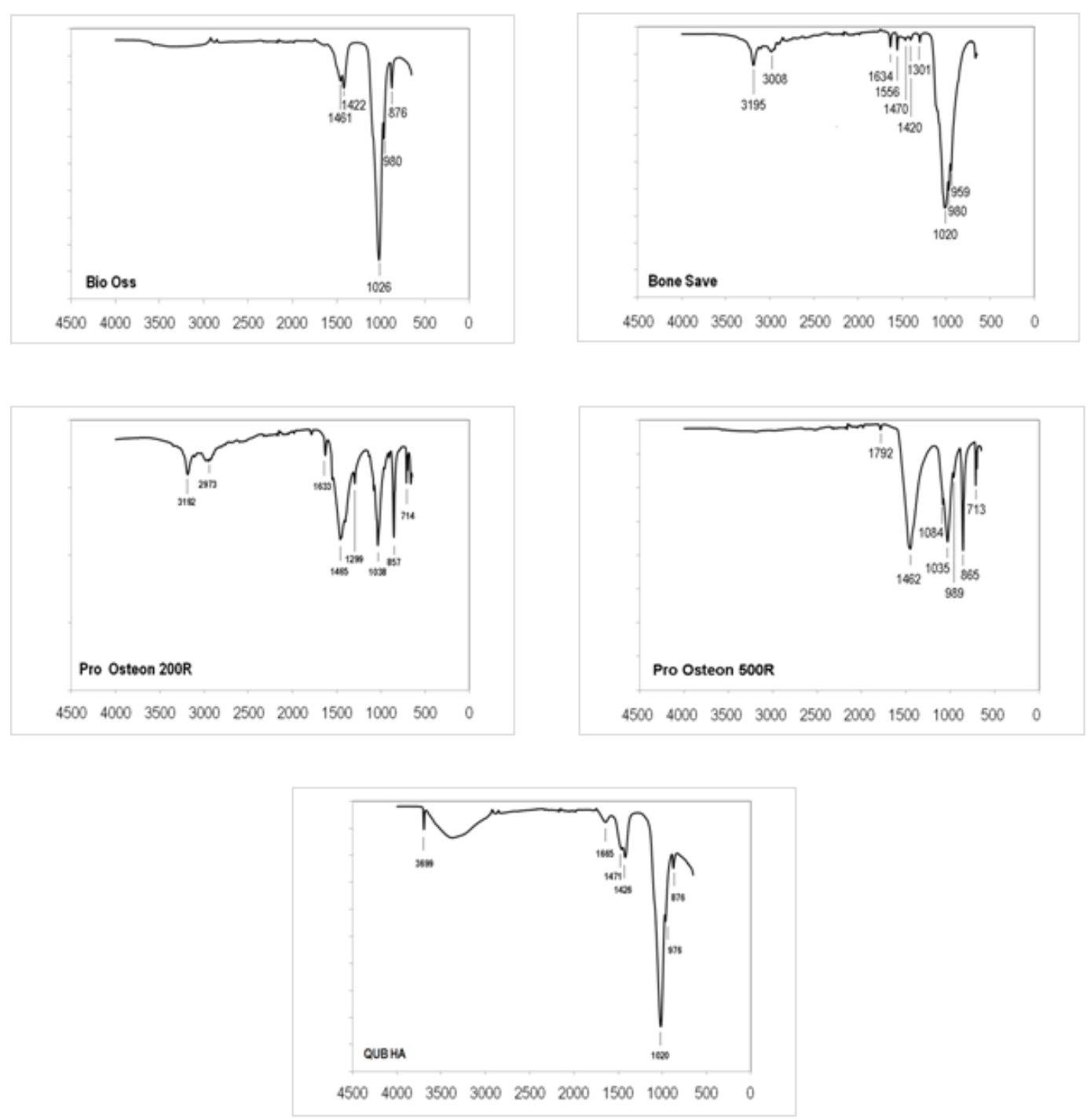

Figure 2: FTIR Spectra of CaP Bone Void Fillers. 
Citation: Walsh PJ, Clarke SA, Nelson J, Maggs CA, Walker GM, et al. (2011) An in vitro Study to Assess the Potential of a Unique Micro porous Algal Derived Cap Bone Void Filler in Comparison with Clinically-Used Bone Void Fillers. J Tissue Sci Eng S1:002. doi:10.4172/2157-7552. S1-002

Page 6 of 9

$\beta$ TCP (87.3\%): HA (12.7\%) respectively. The main phase in the two Pro-Osteon ${ }^{\mathrm{TM}}$ samples was aragonite $(82.4 \pm 4.2 \%)$, with a minor phase of HA, which confirmed the ICP results (Table 3).

The physicochemical results indicated that chemical composition, crystallinity and granule size of QUB HA were most similar to BioOss ${ }^{\circledR}$. These findings support work by Turhani and Weißenböckwho also investigated the cell response of a different QUB HA to BioOss ${ }^{\mathbb{B}}[46]$. The main differences between QUB HA and Bio-Oss ${ }^{\circledR}$ were pore size, granule shape and $S_{\mathrm{BET}}$. All these factors are likely to influence cell response. QUB HA has long uniform-sized cylindrical shaped granules with open microporous extremities, whereas BioOss ${ }^{\circledR}$ is irregular in shape with randomly distributed macroporosity. Gondaet al. found that in vivo, uniform-sized spherical granules achieved better stability and prognosis than irregular-shaped granules [47].

\section{Biological characterization}

Toxicity: Cytotoxicity of the biomaterials was measured after 72 hrs in culture by the release of lactose dehydrogenase (LDH) which occurs upon cell death. No significant difference was found between $\mathrm{LDH}$ release in the control cells and those grown on the bone void filler materials (ANOVA, $\mathrm{p}=0.1346$ ) (Figure 4a). This suggests that the biomaterials are non-toxic to hFOBs.

Cell viability: The optical density (O.D.) absorbance values measured from the XTT assay data are given in Figure 4b. A statistically significant increase in $\mathrm{hFOB}$ viability with time was observed on the samples with larger granule sizes, namely Bone Save ${ }^{\circledR}(p=0.008)$ and Pro-Osteon ${ }^{\mathrm{TM}} 500 \mathrm{R}^{\mathrm{TM}}(\mathrm{p}=0.014)$. No significant difference was observed with time on the BioOss ${ }^{\circledR}$. After 7 days in culture, hFOB viability was significantly higher in Pro-Osteon ${ }^{\mathrm{TM}} 500 \mathrm{R}^{\mathrm{TM}}$ and QUB HA compared to the other biomaterials $(\mathrm{p}<0.001)$. A slight increase in cell viability in Pro-Osteon ${ }^{\mathrm{TM}} 500 \mathrm{R}^{\mathrm{TM}}$ compared to the cells only control is likely to be caused by the larger surface area of the $3 \mathrm{D}$ granules compared to a $2 \mathrm{D}$ flat surface although this difference was not significant $(\mathrm{p}=0.078)$. Our results indicate that the microporous algal-HA wasas effective in
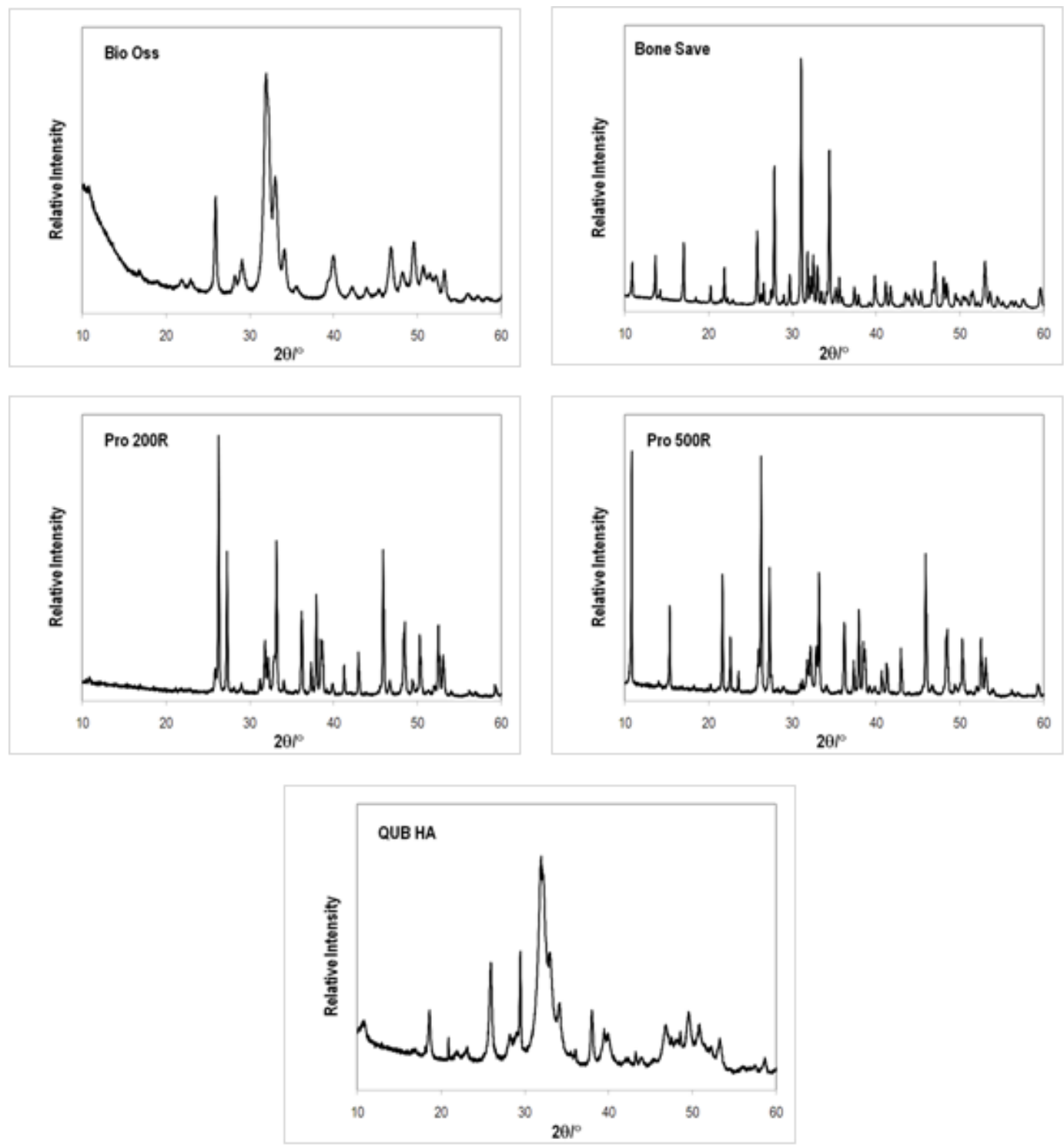

Figure 3: XRD traces of CaP Bone Fillers. 
Citation: Walsh PJ, Clarke SA, Nelson J, Maggs CA, Walker GM, et al. (2011) An in vitro Study to Assess the Potential of a Unique Micro porous Algal Derived Cap Bone Void Filler in Comparison with Clinically-Used Bone Void Fillers. J Tissue Sci Eng S1:002. doi:10.4172/2157-7552. S1-002
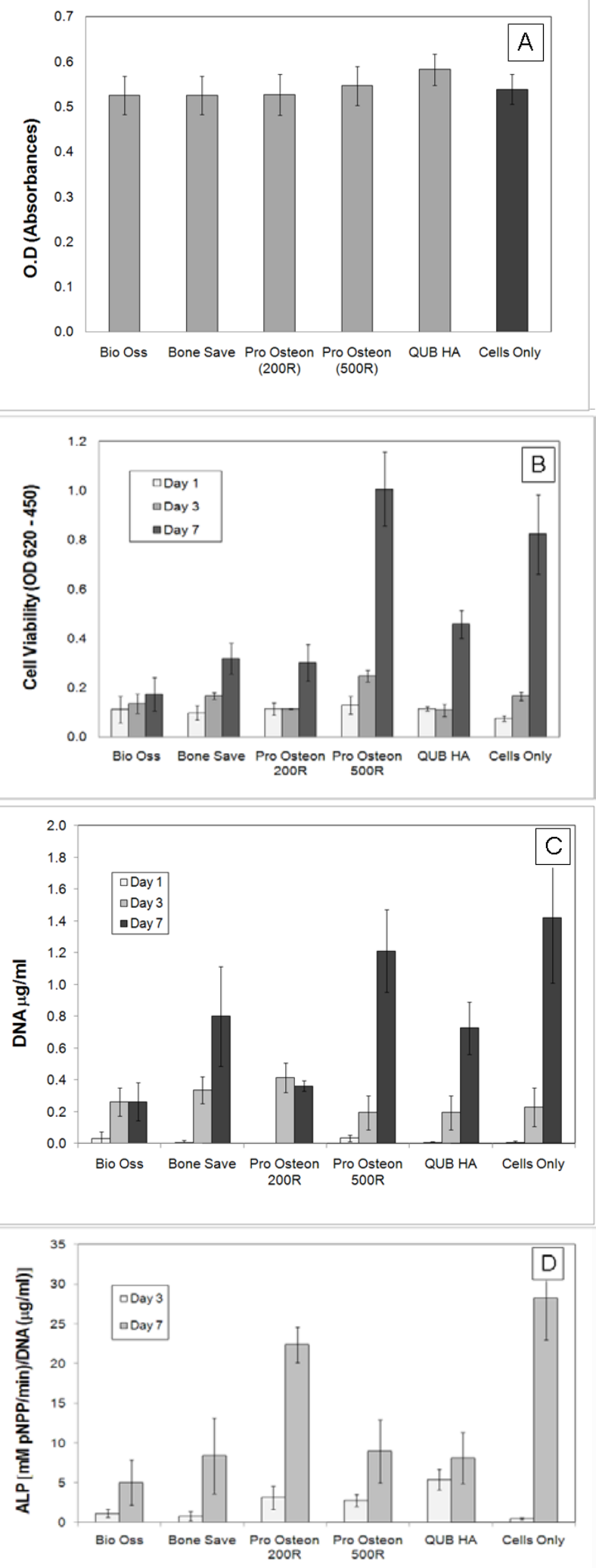

Figure 4: Biological Evaluation (a) LDH Cytotoxicity Assay (b) Optical density measurements for XTT cell viability assay as a function of time (c) Cell proliferation assay incubated at $33^{\circ} \mathrm{C}$ and (d) ALP Activity normalized to DNA (Picogreen Assay) at $39^{\circ} \mathrm{C}$ supporting cell viability as that of its macroporous counterparts. This contradicts findings by Isaacset al. [13] who reported that microporosity in $\beta$ TCP negatively modulates cell viability. This would suggest that other factors such as $S_{\mathrm{BET}}$, particle size and chemical composition also heavily influence the cellular response. For example, the algal-HA we tested was found to have a significantly higher $S_{\mathrm{BET}}$ of $129.8 \mathrm{~m}^{2} \mathrm{~g}^{-1}$, than that of those tested by Isaacs et al. who reported their materials to have $S_{\text {BET }}$ of 0.001 to $1.73 \mathrm{~m}^{2} \mathrm{~g}^{-1}$.

Cell proliferation: The proliferative ability of hFOB cells on the samples was determined by picogreen assay (Figure 4c). At day 1, the cell activity was low in all groups. Between day 1 and day 7, the number of cells in all groups increased significantly, indicating that the biomaterials support proliferation. hFOBs showed the best proliferative capacity on Pro-Osteon $500 \mathrm{R}^{\mathrm{TM}}$ in comparison to the other bone void filler materials. At day 3, no significant difference was observed between any of the materials or cell controls (ANOVA, $\mathrm{p}=0.101$ ). At day 7 , no significant difference was found between Bone Save ${ }^{\circledR}$ and Pro-Osteon ${ }^{\mathrm{TM}} 500 \mathrm{R}^{\mathrm{TM}}$, and the cells-only control $(p=0.145, p=0.127)$. However, the proliferative capacity of hFOBs on QUB HA increased significantly compared to Bio-Oss ${ }^{\mathbb{R}}$ and Pro-Osteon ${ }^{\mathrm{TM}} 200 \mathrm{R}$. When comparing the smaller granules at 7 days, QUB HA showed a better proliferative capacity. Interestingly, proliferation was significantly lower on Pro-Osteon $200 \mathrm{R}^{\mathrm{TM}}$ compared to Pro-Osteon ${ }^{\mathrm{TM}} 500 \mathrm{R}^{\mathrm{TM}}$ at day 7 , despite having a similar chemical composition (Table 2). This indicates that particle size has a significant influence on cell behaviour in vitro and supports work by Wei $\beta$ enböck et al., who found that particle size and substrate geometry significantly influenced cell signaling [30].

Cell differentiation: ALP is one of the most common markers of osteogenic differentiation. ALP activity is expressed as ALP/mg DNA giving the ALP activity per cell, to adjust for significant differences in cell numbers between groups (Figure $4 \mathrm{~d}$ ). A significantly higher level of ALP activity was found between day 3 and 7, with the exception of QUB HA indicating that the cells may differentiate earlier on QUB HA.No significant differences were found in the level of ALP activity between BioOss ${ }^{\circledR}$, Bone Save ${ }^{\circledR}$, Pro-Osteon ${ }^{\mathrm{TM}} 500 \mathrm{R}$ and QUB HA at day $7(\mathrm{p}=0.397)$. Pro-Osteon ${ }^{\mathrm{TM}} 200 \mathrm{R}$ showed a significant increase in ALP activity when compared to these groups, but no significanct difference when compared to the cells-only control $(\mathrm{p}=0.131)$. The physicochemical results showed that QUB HA was most similar to BioOss', however the cell analysis showed that QUB HA supported more cell growth at 7 days and more ALPat day 3.

ALP activity was low on all materials when compared to the cellsonly controls after 7 days with the exception of Pro-Osteon ${ }^{\mathrm{TM}} 200 \mathrm{R}$. These results, in conjunction with those for cell proliferation, suggest that hFOBs on Pro-Osteon ${ }^{\mathrm{TM}} 200 \mathrm{R}$ differentiate earlier than those on the other materials. As cells differentiate, their proliferative capacity decreases, therefore the delayed differentiation seen on all other materials could contribute to the increase in cell number found on ProOsteon $^{\mathrm{TM}} 500 \mathrm{R}$, Bone Save and QUB HA.

In vitro results: The results showed that cells maintain their function on the microporous QUB HA with similar or better biocompatibility than the clinically available bone void fillers tested. In our in vitro studies, instability of bone void fillers could have caused disruption to the cell monolayer formation, thus affecting cell attachment and proliferation butthe rationale of testing the fillers without a fixative agent (e.g. fibrin glue) was to ensure that the cell response was a direct result of the filler. The use of fixatives also had the potential toblock pores, thus reducing the topographical effect of the fillers. 
Citation: Walsh PJ, Clarke SA, Nelson J, Maggs CA, Walker GM, et al. (2011) An in vitro Study to Assess the Potential of a Unique Micro porous Algal Derived Cap Bone Void Filler in Comparison with Clinically-Used Bone Void Fillers. J Tissue Sci Eng S1:002. doi:10.4172/2157-7552. S1-002

Some studies have suggested that larger microporous surface areas increase protein adsorption, enhancing cell attachment [48], however others have argued that protein adsorption does not enhance cell attachment but promotes inducible cells to differentiate down the osteogenic lineage [10]. The $S_{B E T}$ was significantly higher, $129.8 \mathrm{~m}^{2} \mathrm{~g}^{-1}$ for QUB HA, compared to $94.60 \mathrm{~m}^{2} \mathrm{~g}^{-1}$ for Bio Oss ${ }^{\circledR}$ and we found that there was an increase in proliferation on QUB HA but similar levels of ALP expression, suggesting the former effect is more likely.

Our results also suggestthat granule size has a significant effect on the cellular response. By comparing Pro-Osteon ${ }^{\mathrm{TM}} 200 \mathrm{R}$ to $500 \mathrm{R}^{\mathrm{TM}}$ it is possible to assess the influence of different granule sizes on cellular behaviour. The physicochemical data showed that Pro-Osteon ${ }^{\mathrm{TM}}$ $200 \mathrm{R}$ and $500 \mathrm{R}^{\mathrm{TM}}$ have the same pore size, surface area and chemical composition but differ in size of granule (Table 2) however; the biochemical results have shown a significantly higher proliferation of cells on Pro-Osteon ${ }^{\mathrm{TM}} 500 \mathrm{R}$ compared to 200R, whereas differentiation was significantly lower in Pro-Osteon ${ }^{\mathrm{TM}} 500 \mathrm{R}$ compared to ProOsteon $^{\mathrm{TM}} 200 \mathrm{R}$. This may be directly related to the granule size but it is important to note that, although Rietveld analysis quantified the materials with the same phase composition, ICP analysis (Table 3) found elevated levels of Mg in Pro-Osteon ${ }^{\mathrm{TM}} 500 \mathrm{R}$. Other studies have shown that $\mathrm{Mg}$ enhances osteoconductivity by stimulating better cell adhesion and proliferation, andcould also account for the increased cell number [20]. All materials tested were HA, with the exception of Bone Save ${ }^{\circledR}$ which was predominantly $\beta$ TCP with a minor HA phase. This, and other studies, have shown that the manufacturing process used to fabricate bioceramics strongly influences chemistry and pore geometries and thus the cellular response.

\section{Conclusion}

This was a pilot study to assess a novel sustainable microporous algal HA bioceramic as potential bone void filler. Outcome measures were the ability to support proliferation and differentiation of hFOB cells. It was hypothesized that microporous granules would perform equally to macroporosity in terms of the biological response. Although direct comparison between micro and macro scale porosity was difficult due to other chemical and physical variation between materials, the results have clearly shown that the algal-HA (QUB HA) is capable of supporting cellular activity. QUB HA exhibited a similar rate of osteogenic differentiation to all other biomaterials tested, with the exception of Pro-Osteon ${ }^{\mathrm{TM}} 200 \mathrm{R}$. It also showed an increased rate of proliferation and cell viability compared to the other biomaterials, with the exception of Pro-Osteon ${ }^{\mathrm{TM}}$ 500R. One possible explanation is that the interstitial macroporous space between QUB HA granules has provided sufficient interstitial space for cells to penetrate between the granules and fulfil their functions, however this theory needs to be tested in vivo. Our results have clearly shown that HA granules with an interconnected microporous morphology, which provides a high surface area, positively supports cell viability, proliferation and differentiation. Furthermore the results suggest that other factors, such as granule size, specific surface area and surface chemistry, are equally as important as pore size in tissue regeneration. The next stage of this work will focus on in vitro bioresorption profiling of these materials followed by in vivo trials.

\section{Acknowledgements}

This work was funded by an Invest Northern Ireland, Proof of Concept Grant. The authors gratefully acknowledge Stryker HowmedicaOsteonics, Ireland and Biomet, US for supplying their materials for this study.

\section{References}

1. Martin TJ, Seeman E (2008) Bone remodeling: its local regulation and the emergence of bone fragility. Best Practice \& Research Clinical Endocrinology \& Metabolism 22: 701-722

2. Hing KA, Wilson LF, Buckland T (2007) Comparative performance of three ceramic bone graft substitutes. The Spine Journal $7: 475-490$.

3. Best SM, Porter AE, Thian ES, Huang J (2008) Bioceramics: Past, present and for the future. Journal of the European Ceramic Society 28: 1319-1327.

4. Neovius E, Engstrand T (2010) Craniofacial reconstruction with bone and biomaterials: Review over the last 11 years. Journal of Plastic, Reconstructive \& Aesthetic Surgery 63: 1615-1623

5. Voss $\mathrm{P}$, Sauerbier S, Wiedmann-Al-Ahmad M, Zizelmann C, Stricker A, et al. (2010) Bone regeneration in sinus lifts: comparing tissue-engineered bone and iliac bone. British Journal of Oral and Maxillofacial Surgery 48:121-126.

6. Marc Bohner (2010) Resorbable biomaterials as bone graft substitutes Materials Today 13: 24-30

7. Green DW, Bolland BJRF, Kanczler JM, Lanham SA, Walsh D, et al. (2009) Augmentation of skeletal tissue formation in impaction bone grafting using vaterite microsphere biocomposites. Biomaterials 30: 1918-1927.

8. Murugan R, Ramakrishna S (2005) Development of nanocomposites for bone grafting. Composites SciTechnol 65: 2385-2406.

9. Place ES, Evans ND, Stevens MM (2009) Complexity in biomaterials for tissue engineering. Nature Materials 8: 457-470.

10. Li X, van Blitterswijk CA, Feng Q, Cui F, Watari F (2008) The effect of calcium phosphate microstructure on bone-related cells in vitro. Biomaterials 829 : 3306-3316.

11. LanLevengood SK, Polak SJ, Wheeler MB, Maki AJ, Clark SG, et al. (2010) Multiscaleosteointegration as a new paradigm for the design of calcium phosphate scaffolds for bone regeneration. Biomaterials 31: 3552-3563.

12. Bohner M, Loosli Y, Baroud G, Lacroix D (2011) Commentary: Deciphering the link between architecture and biological response of a bone graft substitute. ActaBiomaterialia 7: 478-484

13. Isaac J, Hornez J, Jian D, Descamps M, Hardouin P, et al. (2008) $\beta$-TCP microporosity decreases the viability and osteoblast differentiation of human bone marrow stromal cells. Journal of Biomedical Materials Research Part 86: 386-393.

14. Karageorgiou V, Kaplan D (2005) Porosity of 3D biomaterial scaffolds and osteogenesis. Biomaterials 26: 5474-5491.

15. Honda Y, Anada T, Kamakura S, Morimoto S, Kuriyagama T, et al. (2009) The effect of microstructure on octacalcium phosphate on the bone regenerative property. Tissue Engineering 15: 1965-1973.

16. Yuan HM, Fernandes $H$, Habibovic $P$, de Boer J, Barradas AM, et al. (2010) Osteoinductive ceramics as a synthetic alternative to autologous bone grafting Proc NatIAcadSci 107: 13614-13619.

17. Woodard JR, Hilldore AJ, Lan SK, Park CJ, Morgan AW, et al. (2007) The mechanical properties and osteoconductivity of hydroxyapatite bone scaffolds with multi-scale porosity. Biomaterials 28: 45-54

18. Habibovic P, Yuan H, van der Valk CM, Meijer G, van Blitterswijk CA, et al (2005) 3D microenvironment as essential element for osteoinduction by biomaterials. Biomaterials 26: 3565-3575.

19. Chen P, Lin AYM, Lin Y, Seki Y, Stokes AG, et al. (2008) Structure and mechanical properties of selected biological materials. Journal of the Mechanical Behavior of Biomedical Materials 1: 208-226.

20. Landi E, Carlotta G, Logroscino G, Tampieri A (2003) Carbonated hydroxyapatite as bone substitute. Journal of the European Ceramic Society 23: 2931-2937.

21. Yue W, Park RJ, Kulak AN, Meldrum FC (2006) Macroporous inorganic solids from a biomineral template. J Cryst Growth 294: 69-77.

22. Cunningham E, Dunne N, Walker G, Buchanan (2009) Hugh-solid-conten hydroxyapatite slurry for the production of bone substitute scaffolds. Proc IMechE Part H: J. Engineering in Medicine 223: 727-737. 
Citation: Walsh PJ, Clarke SA, Nelson J, Maggs CA, Walker GM, et al. (2011) An in vitro Study to Assess the Potential of a Unique Micro porous Algal Derived Cap Bone Void Filler in Comparison with Clinically-Used Bone Void Fillers. J Tissue Sci Eng S1:002. doi:10.4172/2157-7552. S1-002

23. Geiger F, Lorenz H, Xu W, Szalay K, Kasten P, et al. (2007) VEGF producing bone marrow stromal cells (BMSC) enhance vascularization and resorption of a natural coral bone substitute. Bone 41: 516-522.

24. Coughlin MJ, Grimes JS, Kennedy MP (2006) Coralline Hydroxyapatite Bone Graft Substitute in Hindfoot Surgery. Foot \& Ankle International 27: 19-22.

25. Bensaid W, Oudina K, Viateau V, Potier E, Bousson V, et al. (2005) De Novo Reconstruction of Functional Bone by Tissue Engineering in the Metatarsa Sheep Model. Tissue Engineering 11: 814-824.

26. Schopper C, Moser D, Wanschitz E, Watzinger E, Lagogiannis G, et al. (1999) Histomorphologic findings on human bone samples six months after bone augmentation of the maxillary sinus with ALGIPORE ${ }^{\circledR}$. L T Effects of Medical Implants 9: 203-213.

27. Kim S, Park CB (2010) Mussel-inspired transformation of $\mathrm{CaCO} 3$ to bone minerals. (2010) Biomaterials 31: 6628-6634.

28. Ivankovic H, GallegoFerrer G, Tkalcec, Orlic S, Ivankovic M (2009) Preparation of highly porous hydroxyapatite from cuttlefish bone. J Mater Sci: Mater Med 20: 1039-1046.

29. Turhani D, Weißenböck M, Watzinger E, Yerit K, Cvikl B, et al. (2005) In Vitro study of adherent mandibular osteoblast-like cells on carrier materials. J Oral Maxillofac Surg 34: 543-550.

30. Weißenböck M, Stein E, Undt G, Ewers R, Lauer G, et al. (2006) Particle size of hydroxyapatite granules calcified from red algae affects the oestrogenic potential of human mesenchymal stem cells in vitro. Cells, Tissue Organs. 182: 79- 88.

31. Tadic D, Epple M (2004) A thorough physicochemical characterization of 14 calcium phosphate-based bone substitution materials in comparison to natura bone. Biomaterials 25: 987-994

32. Blom AW, Wylde V, Livesey C, Whitehouse MR, Eastaugh-Waring S, et al (2009) Impaction bone grafting of the acetabulum at hip revision using a mix of bone chops and a biphasic porous ceramic bone graft substitute. ActaOrthopaedica 80: 150-154.

33. White EW, Shors EC (1989) Coated biomaterials and methods for making same. US Patent No. 4,976,736;

34. Walker GM, Walsh PJ, Buchanan FJ, Maggs CA, Dring M (2006) Process for preparing hydroxylapatite. Patent. GB May 18, 0609815.6; US2010/0015025

35. Walsh PJ, Buchanan FJ, Dring M, Maggs CA, et al. (2008) Low-pressure synthesis and characterization of hydroxyapatite derived from mineralise red algae. Chem. Eng.137: 173-179.
36. Walsh PJ, Walker GM, Maggs CA, Buchanan FJ (2010) Thermal preparation of highly porous calcium phosphate bone filler. J Mater Sci: Mater Med 21 2281-2286.

37. Keeney M, van den Beucken JJJP, van der Kraan PM, Jansen JA, Pandit $A$ (2010) The ability of a collagen/calcium phosphate scaffold to act as its own vector for gene delivery and to promote bone formation via transfection with VEGF165. Biomaterials 31: 2893-2902.

38. Joschek S, Nies B, Krotz R, Göpferich A (2000) Chemical and physicochemica characterization of porous hydroxyapatite ceramics made of natural bone. Biomaterials 21: 1645-1658.

39. Wopenka B, Pasteris J.D (2005) A mineralogical perspective on the apatite in bone Mater. Sci. Eng.C 25: 131-143

40. BS ISO 13779 - 1:2000. Implants for surgery - Hydroxyapatite - Part 1 : Ceramic hydroxyapatite.

41. Boanini E, Gazzano M, Bigi A (2010) lonic substitutions in calcium phosphates synthesized at low temperature. ActaBiomaterialia 6: 1882-1894.

42. Walters MA, Leung YC, Blumenthal NC, Konsker KA, LeGeros RZ. (1990) A Raman and infrared spectroscopic investigation of biological hydroxyapatite. $J$ InorgBiochem 39: 193-200.

43. Jinawath S, Polchai D, Yoshimura M (2002) Low-temperature, hydrothermal transformation of aragonite to hydroxyapatite. Materials Science and Engineering: C 22: 35-39.

44. Wilson RM, Elliott JC, Dowker SEP (2003) Formate incorporation in the structure of Ca-deficient apatite: Rietveld structure refinement. Journal of Solid State Chemistry 174: 132-140.

45. Xu JL, Khor KA, Sui JJ, Zhang JH, Chen WN (2009) Protein expression profiles in osteoblasts in response to differentially shaped hydroxyapatite nanoparticles. Biomaterials 30: 5385-5391.

46. Turhani D, Watzinger E, Weißenböck M, Cvikl B, Thurnher D, et al. (2005) Analysis of Cell-Seeded 3-Dimensional Bone Constructs Manufactured In Vitro With Hydroxyapatite Granules Obtained From Red Algae. Journal of Oral and Maxillofacial Surgery 63: 673-681.

47. Gonda Y, loku K, Shibata Y, Okuda T, Kawachi G, et al. (2009) Stimulatory effect of hydrothermally synthesized biodegradable hydroxyapatite granules on osteogenesis and direct association with osteoclasts. Biomaterials 30: 43904400

48. Hing KA (2005) Bioceramic bone graft substitutes: influence of porosity and chemistry. IntAppl Ceram Tecnol 2: 184-199. 